\title{
Practical experience in teaching inventory management with Edublogs
}

\author{
Julio J. Garcia-Sabater ${ }^{1}$, Pilar I. Vidal-Carreras ${ }^{1}$, Cristina Santandreu-Mascarell ${ }^{2}$, \\ $\mathrm{M}^{\mathrm{a}}$ Rosario Perello-Marin ${ }^{3}$ \\ ${ }^{1}$ ROGLE. Dpto. Organización de Empresas, Universidad Politécnica de Valencia (SPAIN); ${ }^{2} I G I C$. \\ Dpto. Organización de Empresas, Universidad Politécnica de Valencia (SPAIN); ${ }^{3} D$ pto. Organización \\ de Empresas, Universidad Politécnica de Valencia (SPAIN) \\ jugarsa@omp.upv.es; pivican@omp.upv.es; crisanma@,omp.upv.es; rperell@,upvnet.upv.es
}

Received December 2010

Accepted March 2011

\section{Abstract:}

Purpose: The aim of this paper is to analyze the utility of edublogs in teachinglearning process applied to postgraduate Courses. Particularly, it describes an experience carried out while delivering a Course offered to students, mainly Industrial Engineers, of a certain Master program.

Design/methodology/approach: In the first section of the paper, we perform a literature review with the aim of defining some basic concepts as blog, weblog or edublog. Later on, we compare some educational models to identify best practices related to new technologies, and particularly, to edublogs. Finally, we analyze our experience in a postgraduate Course.

Findings and Originality/value: We have identified best practices on teaching using edublogs and we have applied them to a particular postgraduate Course.

Research limitations/implications: Conclusions are obtained from only one experience (one postgraduate Course). We intend to extend the analysis to more postgraduate Courses and compare the obtained results.

Practical implications: We have applied the previously described methodology and we have discussed advantages and disadvantages of using edublogs. 
Originality/value: We have compiled a wide list of best practices on teaching using new technologies and in particular edublogs. We have also evaluated the experience qualitatively according to such best practices and drawn conclusions that will improve the process.

Keywords: blogs, edublogs, learning, inventory management

\section{Introduction}

The European Higher Education Area (EHEA) implies reconsideration on the existing teaching model to date. Many changes occur, such as application of new technologies, and changing perspective of the student, who become the protagonist of his own learning process. This new situation must be addressed so that changes may not be traumatic for those involved: teachers and students (Canos-Daros \& Ramon-Fernandez, 2010). To do this, Spanish universities need to be more flexible, dynamic, creative and innovative (Pablos Pons, Colás Bravo, González Ramírez, \& Jiménez Cortés, 2007), without losing sight of the pedagogical framework.

In this context, the new Web 2.0 network model has become increasingly important in this process of adaptation to the EHEA (Cuesta Morales \& Gómez Rodríguez, 2008). The web 2.0 model allows any user, without special computer skills, to publish on WWW without effort and almost instantly. However, what characterizes Web 2.0 is mainly the fact of constituting an open forum for collaboration. Among applications that embody the spirit of this new Internet, such as social-networking sites, wikis, video-sharing sites, hosted services, web applications, mashups and folksonomies, we focus this paper in blogs, also called weblogs.

A blog is an online journal that users can continuously update, in their own words (Matheson, 2004). So, blogs are personal journals made up of chronological entries, not unlike a paper diary (Huffaker, 2005). Blogs utilize a simple interface to make it easy for any user to construct, without having to understand HTML or web scripting. In addition, users can even add pictures or audio files to enhance their blog's attractiveness. Furthermore, a blog is interactive (Rodzvilla, 2002) in 
the sense that readers can respond with comments in just a few steps. The features of a blog include: instant publishing of text or graphics to the Web without sophisticated technical knowledge; ways for people to provide comments or feedback to each blog post; the opportunity to archive past blog posts by date; and hyperlinks to other bloggers. According to Maag (2006) students are more likely to satisfy with easy-to-use systems in which they are able to obtain information with fewer steps. In summary, we can think of a blog as a Web based multi-media publishing system, which is very low cost (often free), easy to use, customizable in terms of appearance, content, target audience and hyperlinked to other content over the Internet spread.

All these features highlight the great potential of blogs as a teaching tool facilitating the migration of traditional education systems to today's European convergence (Aguaded Gómez \& López Meneses, 2009; Baumgartner, 2004). Among the main advantages of this tool, should be noted that promotes learning styles proposed in EHEA, ie, autonomous, reflective and active learning. On the other hand, it has high versatility, both in face and distance teaching. Finally, it is a tool whose design cost, access and use are minimal, both teachers and students alike. In this context emerges Edublog term as the union between education and blogs. The main purpose of an Edublog is to support a teaching-learning process in an educational context (Lara, 2005).

On the other hand, it may not be overlooked that students who come to college today belong to the Net Generation (Oblinger \& Oblinger, 2005; Tapscott, 1998). This generation is comprised by those born after 1980 and who have grown with Internet. The way they learn has to do with the generational nature and require new approaches to education. Thus, a proposal for a model of teaching using edublogs understands a blog as a personal tool of the student, so that he can use it in a transverse mode along their academic life and not only within a given class. The teacher's role in this model is that of enabling in this new education area, accompanying the students in their own way of experimentation and learning through Edublog (O'Donnell, 2006). However, it must be considered, when introducing a new technology that reproduces dominant teaching models and simply uses to "doing business as usual, but on new media", that this new technology acquires an undeserved aura of modernity that adds nothing to its didactic function. The mere use of edublogs, like any other new technology, does not guarantee the more effective education itself. The achieved result will depend 
on the approach, objectives and methodology employed to integrate it in a particular educational program (Leslie, 2003).

As a conclusion, an edublog must be considered from two different points of view: on one hand, as a format - with a certain container structure - or ICT tool; and on the other hand, as a process within an own ecosystem in the Network (Downes, 2004) or pedagogical tool. Within this paper, we focus on the pedagogical aspect of blogs. Particularly, we evaluate, from the pedagogical point of view, an experience carried out using blogs on the Course 'Inventory Management'. To do this, we have first reviewed the literature related to best practices on teaching. So, once described in detail the experience in the subject, it is possible to evaluate it qualitatively according to such best practices and to draw conclusions that will improve the process.

The structure of the paper is as follows: in section 2, we review the literature on best practices in education as well as the general framework of the advantages of using new technologies, and specifically Edublog; in section 3, we describe the experience on the Course 'Inventory management'; in Section 4, we evaluate qualitatively the experience according to best practices to draw conclusions.

\section{Review of the related literature}

According to the established structure, we first do a compilation of best practices and principles that are considered important to determine whether the concrete application of Edublog in the learning process of 'Inventory management', enables students to acquire the required skills.

Most of the reviewed literature considered as a starting point the seven principles for good practice in education to the best university education, due to Chickering and Gamson (1989):

1. Good practice encourages contacts between students and faculty.

2. It contributes to develop reciprocity and cooperation among students.

3. It uses active learning techniques.

4. It gives prompt feedback. 
5. It emphasizes the time on task.

6. It communicates high expectations.

7. It respects diverse talents and ways of learning.

These principles are intended as guidelines for teachers, students and the school management, to help improve the quality of teaching and learning. They rest on fifty years of research and on how teachers and students interact among themselves, ie on how students learn and interact with each other, and on how students and faculty communicate among themselves. Although all the above tips apply separately when all are present, their effects are multiplied in an effect known as synergy, where the whole found to be greater than the sum of its parts. Together, they combine six powerful forces in the field of education: Activity, cooperation, diversity, expectations, interaction and accountability.

Following this line, in report of Delors (1996) written by a committee of experts at the request of UNESCO, the four pillars that should guide the education of XXI century were been settled:

1. Learning to know.

2. Learning to do.

3. Learning to live together.

4. Learning to be.

There are some other specific studies which identify other best practices.

For instance, in Epper and Bates (2004) a number of characteristics are identified as good practices:

- The contribution to improve the performance of a process.

- The response to an action based on a systematic experience, documented and tested.

- The application of methods of excellence based on innovation. 
- The identification of best practices allows their extrapolation to other contexts.

Palomo López, Ruiz Palmero and Sánchez Rodríguez (2006) consider as good teaching practices "those which exploit the new technological tools to get the student to practice autonomous learning that motivates them to be constantly learning throughout their lives". They establish that innovation in the classroom should have the following characteristics:

- An effective innovative project that provides activities that can reach a possible end.

- A consistency between the posed targets of the innovation and the means that are planned to achieve them.

- A fully integrated innovation in the educational process.

- An innovation assumed and negotiated by all

Pablos Pons and Jiménez Cortés (2007), believe that through ICT, educational experiences and teaching practices, that integrate digital resources on free software and communication networks, are linked to create new contents and forms of organization, promote other types of educational activities and encourage collaborative work strategies. They conclude in their study that to achieve success, at least three basic characteristics must be met: creativity, flexibility and cooperation.

González and Garcia (2009) evaluate the effectiveness and operation of major national educational blogs through the model of Chickering and Gamson (1989). The aspects under which are assessed are, among others, the relationship between students and student-teachers, the temporal organization of tasks and activities that provide motivation and attention to diversity in learning. So, there are commonalities between the different principles, grouped into three basic features or steps that improve the quality of higher education: Interactivity, Competence Development and Flexibility. Interactivity includes the principles of student-faculty contact, cooperation among students and rapid feedback. Competence development includes active learning, time orientation and motivation. Finally, attention to diversity is included within Flexibility. 
Lledó et al. (2011) identifies the following good practices:

1. Motivation as a fundamental element in learning.

2. Methodologies focused on student participation in the construction of their own learning.

3. The inclusion of ICT as a learning tool.

4. A different focus when referring to assessment.

To summarize these principles and characteristics we propose the following table based on González and Garcia (2009) ideas. It extends the characteristics to look for each of the issues and principles.

\begin{tabular}{|c|c|c|}
\hline Characteristics & I ssues & Principles \\
\hline \multirow{3}{*}{$\begin{array}{l}\text { Interactivity } \\
\text { Cooperation } \\
\text { Learning to live } \\
\text { Learning to be } \\
\text { Response to an action based on a } \\
\text { systematic, documented and } \\
\text { experienced experience. } \\
\text { Innovation assumed and negotiated. } \\
\text { Integrated innovation. }\end{array}$} & Student-teacher contact & $\begin{array}{l}\text { Encourage contact between } \\
\text { students and the institution }\end{array}$ \\
\hline & $\begin{array}{l}\text { Cooperation between } \\
\text { students/users }\end{array}$ & $\begin{array}{l}\text { Help to develop reciprocity } \\
\text { and cooperation among } \\
\text { students }\end{array}$ \\
\hline & Quick feedback & Make comments quickly \\
\hline \multirow{3}{*}{$\begin{array}{l}\text { Competence development } \\
\text { Learning to know } \\
\text { Learning to do } \\
\text { Including ICT } \\
\text { I mprove the design of a process. } \\
\text { Application of methods of excellence } \\
\text { based on innovation. } \\
\text { Consistency between objectives and } \\
\text { means. } \\
\text { Effective innovative project. }\end{array}$} & $\begin{array}{l}\text { Active learning } \\
\text { (competence) }\end{array}$ & $\begin{array}{l}\text { Use active learning } \\
\text { techniques }\end{array}$ \\
\hline & $\begin{array}{l}\text { Temporal orientation } \\
\text { (competence) }\end{array}$ & $\begin{array}{l}\text { Emphasize the time factor } \\
\text { of the tasks }\end{array}$ \\
\hline & Motivation (competence) & Convey high expectations \\
\hline $\begin{array}{l}\text { Flexibility } \\
\text { Extrapolation to other context }\end{array}$ & Attention to diversity & $\begin{array}{l}\text { Respect diverse talents and } \\
\text { ways of learning }\end{array}$ \\
\hline
\end{tabular}

Table 1. "Characteristics, issues and principles of education". Source: Compiled from González and García (2009). 
With the assumption of these characteristics, aspects and principles, and the introduction of technology or tools, a new front sight on the educational model to the new paradigm of teaching and learning is started:

- From a teacher focused more on their expertise and knowledge, to a teacher-facilitator of learning who enables that, what he explains and what he knows is presented among students.

- From a student receiving all that you explain to his/her memory, to a constructor student that takes an active part in building their knowledge.

- From an individualistic and isolated student, to a student who learns interactively and collaboratively with peers.

Therefore, the use of Table 1 for the qualitative assessment of the experience in question, developed in detail in Section 3, appears to be a good methodology.

After entering the general framework, we set the specific framework of Edublogs in its educational aspect. According to Lara (2005) the first networks of teachers who experimented with edublogs emerged in the Anglo-blogosphere, as for instance, the British portal Schoolblogs.com - which has been operating since 2001- and the Education Bloggers Network group (http://www.ebn.weblogger.com/), US-based. However, one of the biggest supporters of the introduction of blogs in academia was led by Harvard University (http://blogs.law.harvard.edu/about), by Dave Winer, in spring 2003. One year later, the initiative of the international competition Edublog Awards 2004 (http://www.incsub.org/awards/), likewise served to highlight the most interesting edublogs.

The Leslie Matrix (Leslie, 2003) systematized the principal usage of weblogs in education, that is Edublog (Figure 1). It distinguishes between the use of teacher and student, in their reading and writing aspect, and it offers different possibilities in education. 


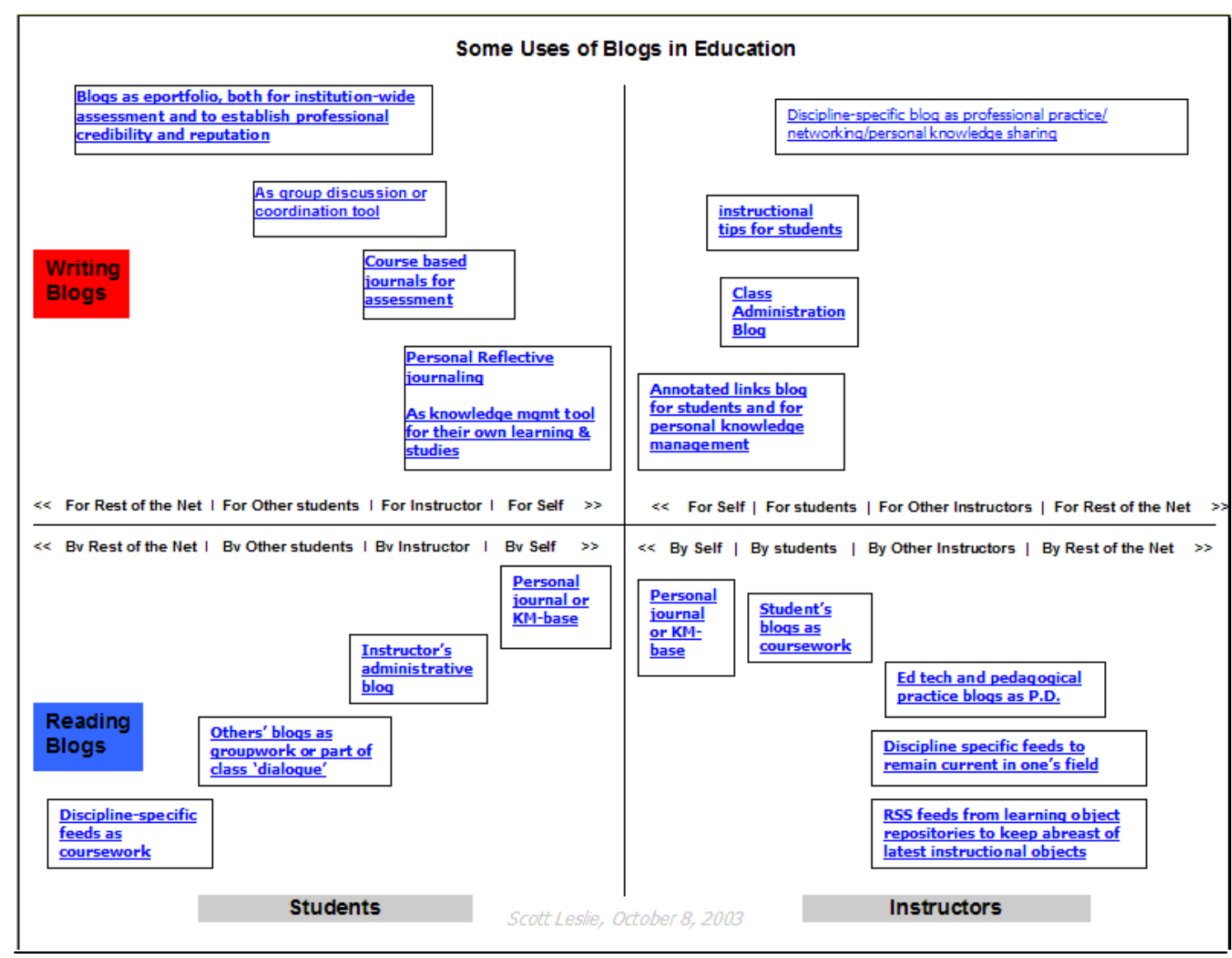

Figure 1. "Leslie Matrix (Leslie, 2003)".

The capabilities and skills that students can develop on their experience as a bloggers, using all its possibilities as a publishing format and a tool for social interaction on the Web are diverse.

In Ferdig and Trammell (2004) the main advantages of Edublog are set out: they help students to become experts ; they increase student interest in learning; they open effective channels for participation; and they bring them closer and offer new perspectives within and outside the classroom. Fiedler (2004) and Wrede (2004) have also highlighted the potential of weblogs as a tool to facilitate dialogue and academic discourse.

The educational aspect of blogs has also attracted the interest of researchers, as evidenced by the growing number of articles in academic journals and conferences to discuss this issue. In Kim (2008) a review of prior literatures on educational blogs and traditional CMC (Computer-mediated communications) applications by analyzing benefits of educational blogs over traditional CMC tools is presented. 
Currently numerous studies have focused on the use of social network systems such as blogs and Wikis in educational settings (Divitini, Haugalokken, \& Morken, 2005; Glogoff, 2003; Huck, 2007; Huffaker, 2005; Lin \& Yuan, 2006; Maag, 2005). There are other authors who explore the use of blogs as a reflective platform in the training processes of English as a Foreign Language (EFL) student teachers (Yang, 2009). Recently, in Duffy and Bruns (2010) an overview of each technology blogs, wikis and RSS feeds will be presented with pragmatic suggestions for their incorporation into the student learning experience.

\section{The experience}

This study case has been developed in the context of the course 'Inventory Management' taught in an official master of the Universidad Politécnica de Valencia. The course is a core course of 4.5 credits which is delivered during the first semester. During the 2010-2011 academic year, 16 students were enrolled in the course, and all of them attend regularly to the classes and practices.

The profile of students is divided almost equally between newly qualified students who want to continue their education and come from technical careers, and professionals who have to balance work with the official Master.

Creating a blog and frequent updating of its inputs has a weight of $20 \%$ of the final grade; the rest of the grade is obtained from other methods of continuous assessment throughout the course. The evaluation of each of the posts is done in a quantitative and qualitative. For the quantitative evaluation, we use specific software which gets the data from each of the posts and gives information on number of entries, words per entry and total words, number of links and number of photos. To mark this, the number of entries was considered as well as links added per student; taking into account the global information the lecturer proceeded to mark the participation of each student.

This information needs to be qualitatively adjusted by correcting this punctuation depending on the quality of inputs, both in format and content. Due to the novelty of the teaching resource for the students, special emphasis was made on the importance of the blog as a teaching resource and as part of the evaluation. 


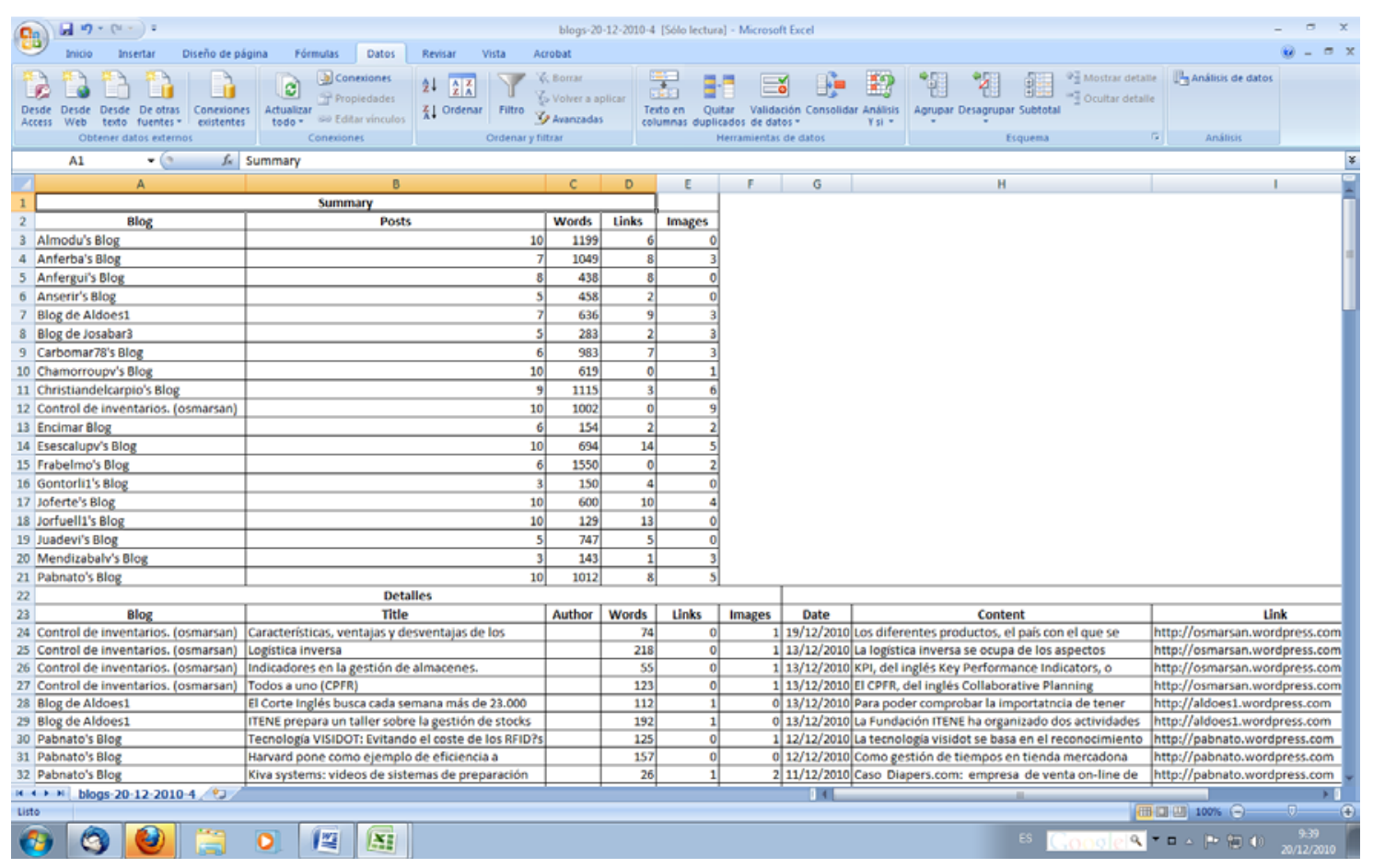

Figure 2. "Excel to analyze the blog".

This importance was transmitted verbally during the first class, during which we explained also the structure of the course and general rules to be followed. Additionally, we spend the whole second class, lasting two hours, in creating the blog and the introduction of the first post. This activity proved necessary due to the fact that many students had troubles creating the blog and the configuration with the appropriate characteristics. If we had left this issue as homework for the student, it likely would have delayed a couple of weeks. One of the requirements of the course is the creation of the blog using "Wordpress". This restriction is due to the software used for quantitative analysis of the aprotic to each blog. This software has been developed previously by the research group of faculty.

During the third class, we spent the first half an hour, reviewing the blog entries and discussing entries in group. We tried to identify strengths and weaknesses of each post. In this way, we created a standard, shared by all, in what should be an entry:

- Entries must not be too long in its content; however, it must synthesize the information they convey.

- Pictures are recommended but should be related to a particular entry. 
- As for links to videos are concerned, these are recommended if visually expose the issues, but they should include at least an introduction, and if necessary an approximation of the relevant minutes. Example: "[...] the most interesting part is at minute $5 "$.

- We also identified the suitability of links to other web sites, but always clarifying in the entry the purpose of putting the link.

- Never copy a lot of information on another website. If there is much information to display summarized and cited the source.

- Cite always the source of information.

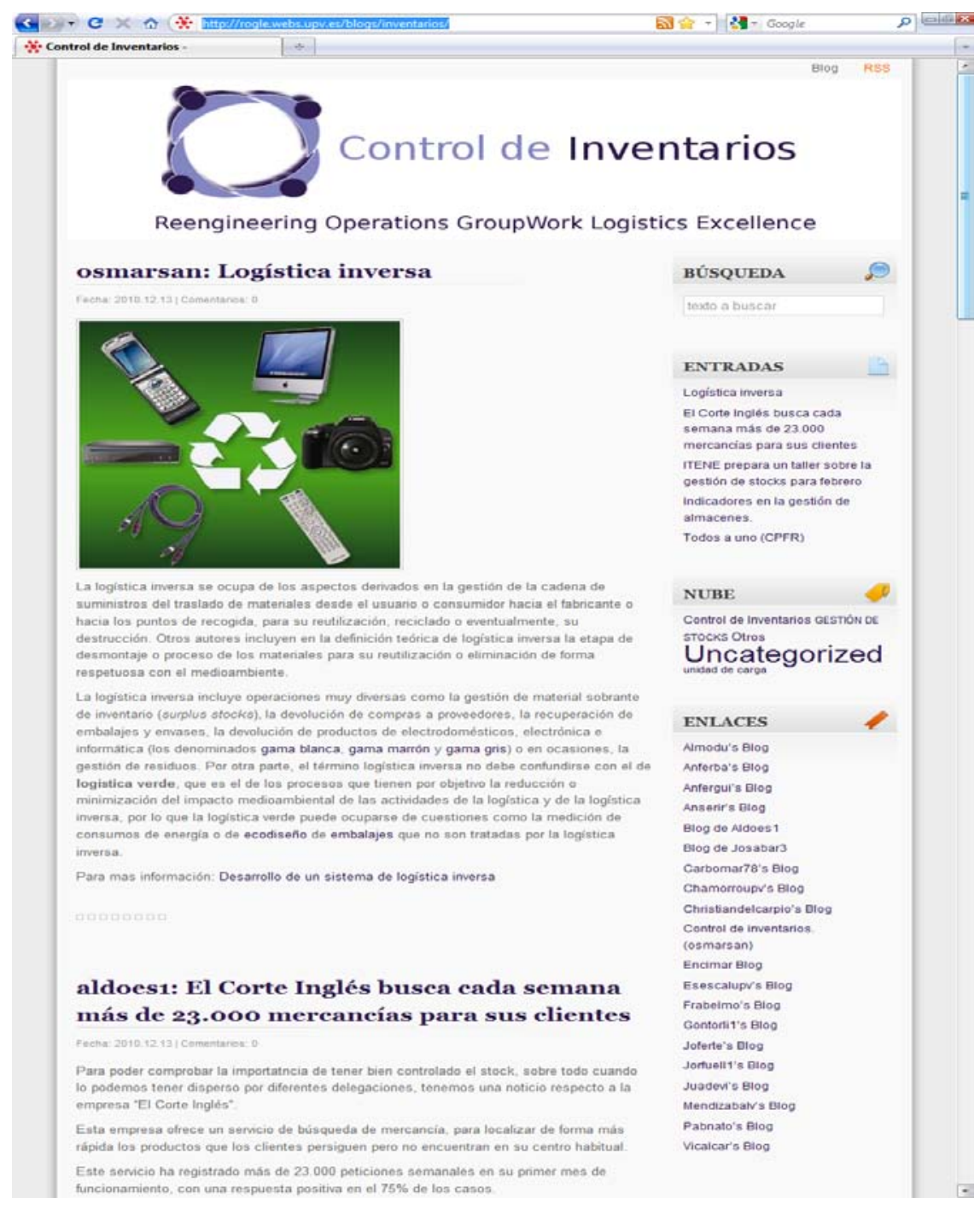

Figure 3. "Overview of a blog". 
During the following classes, the professor stressed these ideas to avoid the typical situation of 'indiscriminately copying information' from other sources, even without citing them. It should be noted that, in order to keep alive the tool, it must be remembered periodically within the class that to fill in the blog is part of the course. The teacher also reminded regularly agreed criteria on what is considered a good blog.

The subject of blogs can be either on the issues that have already been explained either on the topics to be explained, or peripheral issues that students consider important to him or to share with the rest of their colleagues.

Once created individual blogs, a planet was created for the subject. In computing science, the word planet is used to refer to a website whose content is exclusively composed of messages of a set of blogs that usually share a common theme. In this way, both teacher and students can view all entries of the students, without having to change web site. The planet of this study case can be found at the following Website: http://rogle.webs.upv.es/blogs/inventarios/

The teacher, during all classes, accesses with the students, to the website that hosts the planet in order to either review with them the issues that have already been seen in previous classes, or either introduces aspects that are to be treated during the course shortly and it is reflected in entries. For entries that include peripheral issues, the teacher tries to link them with the subject and emphasize the most important aspects of these entries.

\section{Analysis of the experience}

We found that the use of this teaching resource is considered a novelty for most students, since it is not usual that they have previously used. In addition, we found that none of the students also had created a blog for any other use.

After the experience of the class, and as a result of observation and conversation with students, it was found that, although it is assumed that some of the students are already supposed members of the Net Generation Tapscott (1998), it still can not be assumed that all the students have mastered the use of information technology. 
Despite these difficulties for starting, all the students finally agree that the activity is useful and workable, and they also assume that they can learn aspects very interesting for everyone. In this way we cover two of the properties required to any innovation project; that is, an innovation accepted by all, and activities that can lead to an end. Moreover, innovation is integrated into the educational process of the subject and is consistent with the objectives. These two aspects complete the set of characteristics that should require any proposed educational innovation (Palomo López et al., 2006).

Despite the difficulty of students by using these tools, most of them agree that the future of teaching goes through the use of such tools. In this way, and thanks to them, students can go deeper into the part of the subject that most interests them and investigate on their own. Thus we find that blogs are an important tool based on one of the pillars set in the report of Delors (1996). Edublogs allow students to develop autonomous learning and greater freedom to delve into the topics that interest them. On the other hand, the tool can identify the issues of greatest interest to students, so that teachers can adapt the subject, while respecting the established teaching guide, in order to develop those areas most in demand each academic year. Another of the advantages of this tool is the fact that the student learns to do through writing the blog and receive feedback from the teacher and their classmates. This feedback exists at the beginning of the class because the lecturer starts by commenting the work done in blogs and encourage students to participate in the discussion talking about their own posts and the colleagues.

One can see that while there are students who write about themes focused on the subject or related to it either, there are other students who are more focused on adjacent areas, but have not been addressed directly in the subject itself. When asked for the reasons, students respond that the issues discussed by the teacher seems to have been exhausted; i.e. there is no more to add. Although it should be noted that, while this is not entirely true, since you can always go deeper, the students seem to prefer to go collecting information adjacent to focus more on their own interests. In this way, it can be linked learning with interests, needs, experiences or career prospects of students as well as making the student the protagonists of their learning (Lledó et al., 2011).

Another problem to which the teacher must face is the reluctance of students to make entries on topics that they do not dominate. Many of the students argued 
that writing a blog is to be an expert on the subject and they are being formed at that time. This is a barrier to be overcome, making it known that they are not creating a blog for experts but a blog for learning; the teacher may also force the writing entries, until the students do it naturally.

Before the completion of the course, the teacher asks the students information on the development of the subject and more specifically on the use of blogs. Students indicate, as the positive side, that it has allowed them progress by themselves in areas that have interested them most of the course. In addition, they can see the application of the topics covered in the course since most of the entries have to do with the practical application of the theory explained in class.

There seems to be unanimity on the fact that this methodology can be particularly interesting subjects of their full interest. In fact, some students suggest the possibility of creating a blog of topics that may be interesting, if only as a repository of information.

The teacher of the course argues that, by analyzing the entries of each of the blogs in the planet, it can be seen that, at least $70 \%$ of them are interesting or very interesting issues that are not to deviate too much from the subject of the course, ie covering course objectives and consistent with it. In fact, one of the aspects that should be taken into account when using this methodology, is to limit the time of preparation of classes where the teacher discusses the blog entries for display in class, as having many students by creating multiple entries for weeks, there are large amounts of interesting information, which leads to spending too much time "diving" in the post or the links on it. On average, the lecturer has spent 45 minutes per class reviewing the entries and looking for additional information to prepare the discussion in class and to related to link the topics from the blog to the topics of the subject.

Finally, note that this blog can not be classified strictly into any of the definitions referred to in the Leslie matrix (Leslie, 2003). The blog could include a blog-specific content to share professional knowledge, but this definition is subsumed as blog writing by the instructor, and in this case is written by students seeking information and experts and share their peers. 


\section{Conclusions and future research}

The use of edublogs as learning tools seems to meet the expectations both the teacher and the students. The teacher has ensured that the students become interested in a subject that initially looked like a formality despite belonging to a master's degree. Moreover the course the student focuses on the party most interested, although adjacent issues.

The platform used to share blogs cooperative learning also allows therefore a website with much useful information that allows the teacher to highlight the most important aspects for students and linking with other topics of interest.

As a future line of work proposes the use of the blogging tool in core subjects in some degree, that is, the subjects that students consider important and / or more useful, and therefore they naturally pay more attention. In order to analyze all the potential that seems to have the tool.

Another future line to deep in is the improving of the evaluation of entries and the feedback provided to students in class. It was desirable that students could evaluate their colleagues in order to facilitate the management of the system to the lecturer (quantitative evaluation is easy and quick, but qualitative evaluation is not).

\section{Acknowledgement}

Partially financed by the project "El uso de blogs como herramienta de enseñanzaaprendizaje" (PIME-A003/10) from Universidad Politécnica de Valencia.

\section{References}

Aguaded Gómez, J. I. \& López Meneses, E. (2009). La blogosfera educativa: nuevos espacios universitarios de innovación y formación del profesorado en el contexto europeo. REIFOP, 12(3), 165-172.

Baumgartner, P. (2004). The Zen Art of Teaching-Communication and Interactions in eEducation. Paper presented at the Citeseer (pp. 3-89958).

Canos-Daros, L. \& Ramon-Fernandez, F. (2010). La aplicación de las tics en el aprendizaje de disciplinas jurídicas aplicadas en carreras técnicas en el marco de 
la convergencia europea. Paper presented at the Eje temático D. Educación y aprendizajes.

Chickering, A. W. \& Gamson, Z. F. (1989). Seven principles for good practice in undergraduate education. AAHE Bulletin, 39(7), 3-7.

Cuesta Morales, P. \& Gómez Rodríguez, A. M. (2008). Web 2.0 e Educación. Revista de Formación e Innovación Educativa Universitaria. Revista de Formación e Innovación Educativa Universitari, 1(2), 52-57.

Delors, J. (1996). Learning: The Treasure Within. Report to UNESCO of the International Commission on Education for the Twenty-first Century. United Nations Educational Science, and Cultural Organization, 7, place de Fontenoy, 75352 Paris 07 SP, France.

Divitini, M., Haugalokken, O., \& Morken, E. M. (2005). Blog to support learning in the field: lessons learned from a fiasco. Paper presented at the IEEE (pp. 219221).

Downes, S. (2004). Educational blogging. Educause review, 39 14-27.

Duffy, P. D. \& Bruns, A. (2010). The use of blogs, wikis and RSS in education: A conversation of possibilities.

Epper, R. M. \& Bates, T. (2004). Enseñar al profesorado como utilizar la tecnología: Buenas prácticas de instituciones líderes. Editorial UOC.

Ferdig, R. E. \& Trammell, K. D. (2004). Content Delivery in the 'Blogosphere'. The Journal Technological Horizons In Education, 31(7), 12-16.

Fiedler, S. (2004). Personal webpublishing as a reflective conversation tool for selforganized learning. Paper presented at the Viena: Zentrum für Wissenschaftliche Forschung und Dienstleistung. (pp. 216).

Glogoff, S. (2003). Blogging in an online course: a report on student satisfaction among first-time bloggers. Paper presented at the Citeseer (pp. 2160-2162).

González, R. \& García, F. E. (2009). Propuesta de un modelo de medición del desarrollo de los blogs educativos. Una aplicación empírica al sistema educativo español. Revista de Formación e Innovación Educativa Universitaria, 2(4), 8-20. 
Huck, S. W. (2007). Reform in statistical education. Psychology in the Schools, 44(5), 527-533.

\section{doi: $10.1002 /$ pits. 20244}

Huffaker, D. (2005). The educated blogger: Using weblogs to promote literacy in the classroom. AACE J ournal, 13(2), 91-98.

Kim, H. N. (2008). The phenomenon of blogs and theoretical model of blog use in educational contexts. Computers \& Education, 51(3), 1342-1352.

doi: 10.1016/j.compedu.2007.12.005

Lara, T. (2005). Blogs para educar. Usos de los blogs en una pedagogía constructivista. Revista Telos, 65, 86-93.

Leslie, S. (2003). Matrix of some uses of blogs in education. Retrieved 2010, from http://www. edtechpost.ca/mt/archive/000393. html

Lin, H. \& Yuan, S. (2006). Taking blog as a platform of learning reflective journal. Advances in Web Based Learning, 38-47.

Lledó, A., Herrera, L., Roig, R., Perandones, T. M., Sánchez, F. J., Jiménez, M. D. et al. (2011). Buenas prácticas en el marco del EEES: innovación en metodologías docentes y evaluación de los aprendizajes. EDUTIC- ADEI (Educación y Tecnologías de la Información y Comunicación- Atención a la Diversidad. Escuela Inclusiva). Grupo de Investigación Interdisciplinar en Docencia Universitaria (GIDU). Universidad de Alicante. Departamento de Psicología Evolutiva y Didáctica Universidad de Alicante. Departamento de Didáctica General y Didácticas Específicas.

Maag, M. (2005). The potential use of" blogs" in nursing education. Computers Informatics Nursing, 23(1), 16. doi: 10.1097/00024665-200501000-00005

Maag, M. (2006). Podcasting and MP3 players: Emerging education technologies. Computers Informatics Nursing, 24(1), 9. doi: 10.1097/00024665-200601000-00005 
Matheson, D. (2004). Weblogs and the epistemology of the news: some trends in online journalism. New Media \& Society, 6(4), 443.

\section{doi: $10.1177 / 146144804044329$}

O'Donnell, M. (2006). Blogging as pedagogic practice: Artefact and ecology. Asia Pacific Media Educator, 17, 5-19.

Oblinger, D. G. \& Oblinger, J. L. (2005). Educating the net generation. Educause.

Pablos Pons, J., Colás Bravo, P., González Ramírez, T., \& J iménez Cortés, R. (2007). La adaptación de las universidades al espacio europeo de educación superior. Un procedimiento metodológico para el diseño de planes estratégicos. Revista de investigación educativa, 25(2), 533-554.

Pablos Pons, J. \& J iménez Cortés, R. (2007). Buenas prácticas con TIC apoyadas en las Políticas Educativas: claves conceptuales y derivaciones para la formación en competencias ECTS. Revista Latinoamericana de Tecnología Educativa, 6(2).

Palomo López, R., Ruiz Palmero, J., \& Sánchez Rodríguez, J. (2006). Las TIC como agentes de innovación educativa. Sevilla: Junta de Andalucía. Consejería de educación.

Rodzvilla, J. (2002). We've got blog: How weblogs are changing our culture. Basic Books.

Tapscott, D. (1998). Growing up digital. (302 ed.). McGraw-Hill: New York.

Wrede, O. (2004). Personal webpublishing as a reflective conversation tool for selforganized learning. Paper presented at the Viena: Zentrum für Wissenschaftliche Forschung und Dienstleistung. (pp. 237).

Yang, X. H. (2009). Improving teachers' knowledge management with Blog platform. 2008 International Workshop on Geoscience and Remote Sensing, Vol 1, Proceedings, 73-76. 


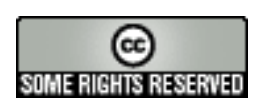

Article's contents are provided on a Attribution-Non Commercial 3.0 Creative commons license. Readers are allowed to copy, distribute and communicate article's contents, provided the author's and Journal of Industrial Engineering and Management's names are included. It must not be used for commercial purposes. To see the complete license contents, please visit http://creativecommons.org/licenses/by-nc/3.0/. 